\title{
ANALYSIS OF INVENTORY MANAGEMENT FOR AGRO AND ORGANIC PRODUCT SATISFYING CUSTOMER WITH MAXIMUM PROFIT USING EOQ MODEL
}

\author{
Debasmita Samal \\ Department of Mathematics \\ COEB, Bhubaneswar, Odisha
}

\author{
Abdul Kalam \\ Department of Mathematics \\ EATM, Bhubaneswar, Odisha, India
}

\begin{abstract}
Inventory management of agro-based industry (dairy product) is a challenging tax because due to its perishable nature.EOQ model has its importance \& role for proper management of this category of Inventory. The success of many businesses is related to their ability to provide goods and services at right time and in right place. Different organization adopt different inventory control methods to manage their inventory to avoid stock-out and overstock. This paper analyses possible parameters of existing literature, concentration, description of characteristics and of EOQ inventory control model that have been developed and can solve the Problem in this field $\&$ will provide the customer satisfaction with profit maximization.
\end{abstract}

Keywords - Agro products, Inventory management, EOQ, Holding cost, Ordering cost

\section{INTRODUCTION}

The most important factor in organization and the proportion of inventories to total asset is Inventory management. Inventory management system has mainly two concerns, one is level of customer service i.e. to have right goods, in right place and at right time and other is cost of ordering and carrying inventories. Inventory management is not proper in this market complex where five retail shops are there which is situated in Odisha. In this paper it is named as the market complex $\mathrm{ABC}$ because the identity of this market complex is protected. These retail shops are facing many problems when overstock or stock out occurs in the market warehouse. So to overcome these problems various methods can be used like JIT (Just in Time), Value stream mapping, EOQ and ROP etc. In this paper an EOQ method is selected for research work.

Bill Roach 2005 [1], explains how the origin of the Economic Order Quantity started in his article, "Origin of the Economic Order Quantity formula; transcription or transformation?" published in 2005. Roach explains that the Economic Order Quantity (EOQ) has been a well-known formula that calculates the optimal economic order quantity.
He also mentions how Ford W. Harris contribution to the EOQ formula was significant. He wrote formula of EOQ in 1915, when he was still an undergraduate student. The formula of EOQ is used in business, also in engineering.

India as an agriculture base economy has its requirement for agriculture growth through the establishment $\&$ development of agro based industry which can be held \& possible through successful business of agricultural products where as success of any business is related to their ability to provide the satisfaction towards the customers and maximum selling of its product, has the required goods and services in the right place \& time or proper/effective inventory management. An effective inventory management should maintain sufficient finished goods inventory for smooth sales operation, efficient customer services, minimization of the carrying cost and time, control investment in inventories, keep it at an optimum level, permits a better utilization for available stocks by facilitating interdepartmental transfers with a company. Effective inventory management for manufactured products is with the application of various models where as Agriculture products with its inventory is big issue today need more attention because, it is difficult task to manage the agriculture products and its inventory due to their unique features such as the perishable nature, limited and unpredictable supply, prices and decision of how much to sell. This is the real case in the Odisha market.

In this case characterization of the optimal inventory (selling) policies has to be developed for variety of cost functions, Here the author has taken the linear cost which may be functioned $\&$ if will be relevant in practice, can derive closed form expressions for the optimal policies and the optimal discount profits with the help of EOQ model as a tool for its implementation and effective inventory management. Here the product is Ghee. Traditionally, ghee is always made from bovine milk, as cows are considered sacred, and it is a sacred requirement in Vedic yajña and homa (fire rituals), through the medium of Agni (fire) to offer oblations to various deities. Fire rituals are utilized for ceremonies such as marriage and funerals. Ghee is required in Vedic worship 


\section{International Journal of Engineering Applied Sciences and Technology, 2021 \\ Vol. 6, Issue 3, ISSN No. 2455-2143, Pages 114-117 \\ Published Online July 2021 in IJEAST (http://www.ijeast.com)}

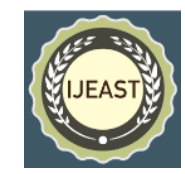

of mūrtis (divine deities), with aarti (offering of ghee lamp) called diȳa or dīpa and for Pañcāmrta (Panchamruta) where ghee along with mishri, honey, milk, and dahi (curd) is used for bathing the deities on the appearance day of Krishna on Janmashtami, Śiva (Shiva) on Mahāśivarātrī (Maha Shivaratri). There is a hymn to ghee. ${ }^{[2]}$ In the Mahabharata, the kaurava were born from pots of ghee. ${ }^{[3]}$ Finding ghee pure enough to use for sacred purposes is a problem these days for devout Hindus, since many largescale producers add salt to their product.

Here the available data is taken for the analysis with the development of calculated cost, estimates to compare business and the recommended EOQ model to the business to implement \& increase stocks and reduce reorder. Regardless of all other theory, Applying this ,EOQ theory to practice, it is possible to make selling decisions judiciously \& can significantly make outer form of the prevailing practice of selling.EOQ is an inventory model which is for the fixed order size inventory and is a formula for determining the optimal order size that minimizes the sum of carrying costs and ordering cost which has the requirement of the demand forecasting of the particular region or by taking the usage of a particular product and its past data is available.

\section{LITERATURE REVIEW}

Organization's inventory is an important component and its management is vital to the success and cost reduction of the firm's expenditure. In this field of effective inventory management, a number of scholars have done the research and with their suggestions \& findings.

L. Bournee \& D.H.T walker (1977) Company performance depend upon many variables, either depends on sales marketing good human resource or the less production cost.

Wee H M. (1999)," Domestic and international research shows that the agricultural products are perishable products, and their inventory model is based on the study of perishable products. And the core elements in the perishable products are: 1) demand, 2) freshness, 3) loss rate"

J. W Toomy(2000), "The role of inventory management is to maintain a desired stock level for every specific product items, where the systems that plan and control inventory must be based in the product, customer and the process of product that available in the inventory.

Prasad \& TATA (2000) Batching of inventory helps NGOS to save on their transport cost which will eventually save on their total supply chain with total cost.

Wild(2002) recommends, proper warehousing of inventory so that when goods are ordered, they are held at the warehouse or the least item possible minimizing holding cost of inventory. .

Kavalya (2004 ) Total cost model needs to be balanced by ensuring purchase costs, ordering cost and holding costs are minimized so that the firm can reap good profits and maintains its budgetary allocation for nongovernmental organization .
Beamon and Kotleba (2006) explain that reorder level (ROL) is critical for human terrain organizations to achieve optimal efficiency and to be effective. They need to have two reorder levels one that is normal where as a second one that is for emergency cases in case of disaster. This improves performance and customer satisfaction.

Lai \& Chang (2009) it was found out that keeping moderate inventory is good and it enables an organization operate minimal expenses of holding and setup costs; eliminate unwanted lead time produce goods as per customer order. This enables and organization achieve total quality control as efficient and effective supply chain management are implemented in a firm's value chain.

T. Lwiki \& P. B Ojera (2013), Inventory management is a crucial part of a firm because mismanagement of inventory threatens a firm's viability such as too much inventory consumes physical space, creates financial burden and increases the possibilities of damage, spoilage, and loss.

A.Swain, D.Samal, A.Kalam (2018), explain the inventory of potato in odisha market to prevent the loss and farmer's suicide.

\section{ASSUMPTIONS \& NOTATION}

$A$. EOQ model assumes that demand is known and is constant over time.

$B$. No shortages are allowed.

$C$. Lead time for the receipt of orders is constant.

$D$. The order quantity is received all at once.

$E$. The purchase price of item is constant

$E O Q=\sqrt{\frac{2 C_{p} \cdot A}{C \cdot C_{h}}}$

$\mathrm{Q}=$ The EOQ order quantity .this is the variable we want to optimize. All the other variables are fixed quantities.

$\mathrm{A}=$ the annual demand of product in quantity /unit time.

$\mathrm{Cp}=$ the product order cost. This is the flat fee charged for making any order is independent of $\mathrm{Q}$.

$\mathrm{C}=$ Unit cost

$\mathrm{Ch}=$ Holding cost $/$ Unit as fraction of product cost

$\mathrm{A}=$ Demand for the year

$\mathrm{Cp}=$ Cost to place a single order

$\mathrm{Ch}=\mathrm{Cost}$ to hold one unit inventory for a year

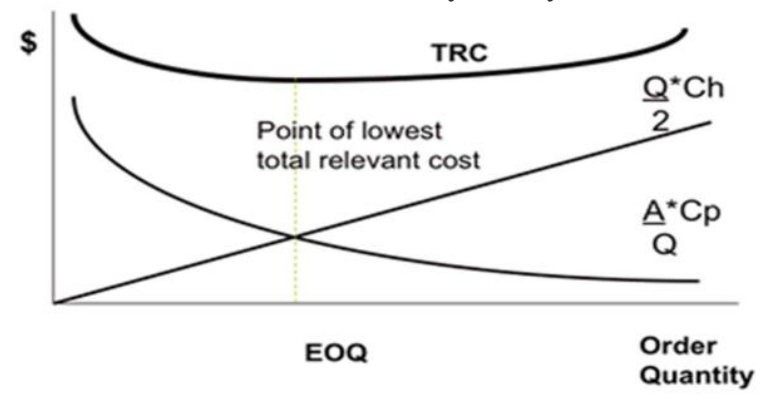




\section{International Journal of Engineering Applied Sciences and Technology, 2021 Vol. 6, Issue 3, ISSN No. 2455-2143, Pages 114-117 \\ Published Online July 2021 in IJEAST (http://www.ijeast.com)}

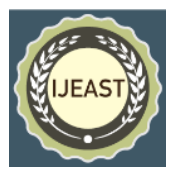

\section{CALCULATION OF EOQ}

It determines the optimal amount of those cost that affected both by the amount of inventories held and the number of orders made. Ordering in bulk at the same time will increase the costs of maintaining a small business, because that will increase the number of stocks in the warehouse , while ordering costs will be lowered. Increasing the number of orders reduces holding costs but increases the costs of ordering .EOQ model minimizes the amount of these costs, which found a formula that shows the connections between the costs of maintaining and ordering and annual demand for the material . Here the authors have taken the data of $\mathrm{ABC}$ market complex where five retail shops are there who sells Ghee. Significant costs affecting the determination of the optimal inventory levels are holding costs and ordering costs. Significant holding costs are only those that differ with respect to inventory levels. This includes the opportunity cost of the holding funds, Invested in stocks, which is reflected by the cost of wanted return from investing in stocks compared with any other investment alternative. For the firm the required return is $25 \%$. In other holding costs, it is included storage and security and electricity and the cost of electricity goes to 12000 for 12 months. In ordering costs there are included costs for transportation which relate to the number of units ordered. Society makes a supply once in every week and the charge is 10000 .

Economic order Quantity (EOQ) can be determined by reflecting the total costs for different amounts of orders through the formula. For the EOQ'S determination, we need the annual demand data, the cost of ordering and cost of holding. In this paper for

experiment we supposed to calculate EOQ for the Ghee which is sold.

Monthly Demand:

\begin{tabular}{|c|c|}
\hline Shop name & Amount of Ghee \\
\hline $\mathrm{S}_{1}$ & 0.85 quintal \\
\hline $\mathrm{S}_{2}$ & 1.2 quintal \\
\hline $\mathrm{S}_{3}$ & 0.8 quintal \\
\hline $\mathrm{S}_{4}$ & 0.75 quintal \\
\hline $\mathrm{S}_{5}$ & 0.9 quintal \\
\hline Total & 4.5 quintals \\
\hline
\end{tabular}

The ABC market complex calculates demand for ghee based on average monthly turnover. It works 365 days a year. So the annual demand for the ghee is -

$\mathrm{D}=4.5$ quintals/one month $\times 12=54$ quintals.

Holding cost $=0.03$ per unit per year

The purchase price for $1 \mathrm{k} . \mathrm{g}$ is Rs 600/- i.e, C=Rs 600/- per K.g

According to the data, they order one time in a month and the total charge is Rs. 300000/-Ordering cost It includes the cost of transportation cost, it orders once in a month a truck of ghee packet charge Rs30, 000 (10\% of Rs.300000/-).

So the price excluding transportation cost is $300000-30000=270000$

Therefore ghee purchased $\frac{27000}{600}=450 \mathrm{k} \cdot \mathrm{g}$

Ordering cost per k.g $=\frac{30000 \times 12}{450}=800$

So $E O Q=\sqrt{\frac{2 \times 5400 \times 800}{0.03 \times 600}}=692.82 \mathrm{k.g}$

So the economic order for the potatoes is approximately 6.9282 quintals per order to minimize the cost.

\section{CONCLUSION}

Economic order quantity (EOQ) inventory model is effective in inventory management by the reduction of ordering, carrying and total cost, is considered as promotional effort for customer satisfaction and developmental pricing strategy for maximization of the profit for the retailer. Here demand is estimated by taking the previous data available and price fixation for a particular product throughout the year, will help the retailer sell the product according to their estimation though production is constant. Inventory order calculation and implication helps to reduce the risk of the retailer. Retailer will get the fixed price from the customer, though it is constant throughout the year. By this effective inventory management a seller or retailer can not only give the customer satisfaction, profit maximization but also can do the responsibility towards society.

\section{REFERENCES:}

[1] Bournee , M.C (1977), , Post-harvest food losses and their control . second regional the neglected dimension in increasing the world food supply . Cornell University, International agriculture Mimeograph.

[2] Wee H M. (1999). Deteriorating Inventory Model with Quantity Discount, Pricing and Partial Back ordering. International Journal of Production Economics, 59(1-3): 511-518.

[3] Toomy , J.W (2000), ' Inventory Management :Principles, concepts\& Techniques, Kluwer Academic Publishers , Norwell, http://du.doi.org/10.1007/928-1- 4615-4363-3

[4] Prasad, S. \& Tata, J.(2000 ), “ Information Investment In Supply Chain Management" Logistics Information Management , 13(1) 33-38.

[5] Wild T. (2002), "Best Practice in inventory Management, Hoboken, John Willey \& Sons.

[6] Kavalya , J.(2004), University Libraries in Kenya, A Study of their practices \& performance. Humber boldt University in Berlin, Berlin unpublished MBAProject. 
[7] Beamen, B.M \& Kotleba S.A (2006), "inventory Modelling for complex Energies in humanitarian relief operations, International Journal of Logistics; Research \& Applications, Vol-9 ,1- 18, retrieved March 2006.

[8] Lai : K.H \& Chang, T.C.E (2009) just in time Logistics, Wey court East, Union Road Farnham Surray GU 97 PT, England, Gower Publishing Limited .

[9] Lwiki T, \& Ojera P.B. (2013), " The impact of Inventory Management Practices in financial performance of sugar manufacturing firm in Kenya", International Journal of Business, Humanities \& Technology, Vol-3, No 5, May 2013.

[10] Swain A, Samal \& .Kalam A(2018), "EOQ as a Profit Maximised \& Customer Satisfied Tool for Agro Industry Inventory Management" International Journal for

Research in Applied Science \& Engineering Technology (IJRASET), Volume 6 Issue VI, June 2018. 